\title{
«GREEN» SYNTHESIS OF ETHYL 4-HYDROXY-2-OXO- 1,2-DIHYDROQUINOLINE-3-CARBOXYLATES
}

\author{
I.V.Ukrainets, O.V.Gorokhova, X.V.Andreeva, N.Yu.Golik
}

National University of Pharmacy, 53, Pushkinska str., Kharkiv, 61002, Ukraine.E-mail: uiv-2@mail.ru

Key words: ethyl 4-hydroxy-2-oxo-1,2-dihydroquinoline-3-carboxylates; pyrido[3,2,1-ij]-quinolines; pyrrolo[3,2,1-ij]quinolines; 3-(1-quinolinyl)propanenitriles» «green chemistry»

One of the most convenient methods for obtaining ethyl of N-substituted 4-hydroxy-2-oxo-1,2-dihydroquinoline-3-carboxylates and their tricyclic analogues at present is condensation of the corresponding anilines with triethyl methanetricarboxylate. In spite of the fact that there are many methods describing the successful performance of this reaction in conditions of laboratory, but unfortunately, all of them appeared to be completely unusable for large production for a variety of reasons. The study of quality of the esters of 4-hydroxy-2-oxo-1,2-dihydroquinoline-3-carboxylic acids by HPLC has shown that all of them contain from 2.4 to $5.6 \%$ of specific admixtures of 4-hydroxy-1,2-dihydroquinolin2-ones. In laboratory conditions these amounts can be neglected, but for industrial manufacture they can turn into great losses. The source of admixtures of 4-hydroxy-1,2-dihydroquinolin-2-ones appearing in crude esters can be only the esters themselves. It is obvious that ester grouping is partially destroyed not in the process of separation of the final products, but during the course of the basic reaction. It has been experimentally proven that the cause of contamination of the target products with the admixtures of the corresponding 4-hydroxy-1,2-dihydroquinolin-2-ones is water, which is present in reagents. Applying the principles of "green chemistry» the alternative for carrying out the syntheses of ethyl 4-hydroxy-2-oxo-1,2-dihydroquinoline-3-carboxylates adapted for industrial manufacture has been suggested on the basis of $\mathrm{N}$-substituted anilines and triethyl methanetricarboxylate.

«ЗЕЛЕНИЙ» СИНТЕЗ ЕТИЛОВИХ ЕСТЕРІВ 4-ГІДРОКСИ-2-ОКСО-1,2-ДИГІДРОХІНОЛІН-3-КАРБОНОВИХ КИСЛОТ

\section{І.В.Українець, О.В.Горохова, К.В.Андреєва, М.Ю.Голік}

Ключові слова: естер 4-гідрокси-2-оксо-1,2-дигідрохінолін-3-карбоксилатів; піридо[3,2,1-іj]-хіноліни; піроло[3,2,1-іj]-хіноліни; 3-(1-хінолініл)пропаннітрили; «зелена хімія»

Одним з найбільш зручних способів одержання етилових естерів N-заміщених 4-гідрокси-2-оксо-1,2-дигідрохінолін-3-карбонових кислот та їх трициклічних аналогів на теперішній час залишається конденсація відповідних анілінів з триетилметантрикарбоксилатом. Незважаючи на те, що методів успішного проведення цієї реакції в лабораторних умовах описано досить багато, всі вони, на жаль, з різних причин виявились зовсім непридатними для маситабного виробництва. Вивчення якості одержуваних естерів 4-гідрокси-2оксо-1,2-дигідрохінолін-3-карбонових кислот методом ВЕРХ показало, що всі вони містять від 2,4 до 5,6\% специфрічних домішок 4-гідрокси-1,2-дигідрохінолін-2-онів. У лабораторній практиці такими кількостями можна знехтувати, але для промислового виробництва вони можуть обернутися значними втратами. Джерелом появи в неочищених естерах домішок 4-гідрокси-1,2-дигідрохінолін-2-онів можуть бути тільки самі ці естери. Очевидно естерне угрупування частково розкладається не при виділенні кінцевих продуктів, а ще в процесі проведення основної реакції. Експериментально доведено, що причиною забруднення цільових продуктів специфрічними домішками відповідних 4-гідрокси-1,2-дигідрохінолін-2-онів є присутня в реагентах вода. Керуючись принципами «зеленої хімії», ми запропонували адаптований під промислове виробництво варіант проведення синтезів етилових естерів 4-гідрокси-2-оксо-1,2-дигідрохінолін-3-карбонових кислот на основі $\mathrm{N}$-заміщених анілінів та триетилметантрикарбоксилату.

\section{«ЗЕЛЁНЫЙ» СИНТЕЗ ЭТИЛОВЫХ ЭФИРОВ 4-ГИДРОКСИ-2-ОКСО-1,2-ДИГИДРОХИНОЛИН-3-КАРБО- НОВЫХ КИСЛОТ \\ И.В.Украинец, О.В.Горохова, К.В.Андреева, Н.Ю.Голик}

Ключевые слова: эфир 4-гидрокси-2-оксо-1,2-дигидрохинолин-3-карбоксилатов; пиридо[3,2,1-іj]-хинолины; пирроло[3,2,1-ij]-хинолины; 3-(1-хинолинил)пропаннитрилы; «зеленая химия»

Одним из наиболее удобных способов получения этиловых эфриров N-замещённых 4-гидрокси-2-оксо-1,2-дигидрохинолин-3-карбоновых кислот и их трициклических аналогов в настоящее время остаётся конденсация соответствующих анилинов с триэтилметантрикарбоксилатом. Несмотря на то, что методов успешного проведения этой реакции в лабораторных условиях описано достаточно много, все они, к сожалению, по разным причинам оказались совершенно непригодными для крупного производства. Изучение качества получаемых сложных эфриров 4-гидрокси-2-оксо-1,2-дигидрохинолин-3-карбоновых кислот методом ВЭЖХ показало, что все они содержат от 2,4 до 5,6\% специфрических примесей 4-гидрокси-1,2-дигидрохинолин-2-онов. В лабораторной практике этими количествами можно пренебречь, но для промышленного производства они могут обернуться значительными потерями. Источником появления в неочищенных эфирах примесей 4-гидрокси-1,2-дигидрохинолин-2-онов могут быть только сами эти эфиры. Очевидно сложноэфирная группировка частично разрушается не при выделении конечных продуктов, а ещё в процессе проведения основной реакции. Экспериментально доказано, что причиной загрязнения целевых продуктов примесями соответствующих 4-гидрокси-1,2-дигидрохинолин-2-онов является присутствующая в реагентах вода. Руководствуясь принципами «зелёной химии», мы предложили адаптированный под промышленное производство вариант проведения синтезов этиловых эфиров 4-гидрокси-2-оксо-1,2-дигидрохинолин-3-карбоновых кислот на основе N-замещённых анилинов и триэтилметантрикарбоксилата. 
The scientific direction "green chemistry» appeared only at the end of the XX-th century, but it has already found a lot of followers in the world chemical community. And this is not surprising since by now environmental protection from the negative effect of chemical enterprises has been changed from initially fashionable trend into vital necessity. Even a shallow analysis of the principles declared by «green chemistry» [1-2] shows that their implementation (even partial) while synthesizing any given chemical product affect positively the various sides of the industrial production - from economic to ecological ones. Therefrom our interest is in the topic imposed by the prospect of entering some new medicines of the range of 4-hydroxy-2-oxo-1,2-dihydroquinoline3 -carboxamides at the pharmaceutical market.

The initial products for obtaining such compounds are, as a rule, lower alkyl esters (more often ethyl) of the corresponding quinolinecarboxylic acids [3-5]. Amidation of the acids themselves is possible [4-6]. However, due to their high tendency to decarboxylation (especially in solution) [7] such methods are used in practice in very rare cases.

One of the most convenient methods for obtaining ethyl of $N$-substituted 4-hydroxy-2-oxo-1,2-dihydroquinoline-3-carboxylates 1 and their tricyclic analogues $\mathbf{2}$ at present is condensation of the corresponding anilines $\mathbf{3}$ or $\mathbf{4}$ with triethyl methanetricarboxylate (Scheme).

In spite of the fact that there are many methods describing the successful performance of this reaction in conditions of laboratory, but unfortunately, all of them appeared to be completely unusable for large production for a variety of reasons. That is why we have proposed the modified method constituting a gradual addition of $N$-substituted aniline into the solution of triethyl methanetricarboxylate in diphenyl oxide heated up to $215-220^{\circ} \mathrm{C}$ [8]. This modifica- tion allows working with great loads and basically can be easily reproduced industrially. At the same time the necessity of using diphenyl oxide as the «weakest link» of the whole synthetic chain can become an extremely serious problem with time. On the one hand, this thermal medium has excellent characteristics of thermal and chemical stability. Its benefits are also low toxicity for many animals $[9,10]$ and human $[11]$. But on the other hand, it should be remembered that even with all things considered diphenyl oxide is added to the list of chemicals that are hazardous for the environment. It is inflammable, can form high-toxic decomposition products and smoke when burning. Finally, ingress of this material into waste water and water supply is not absolutely permissible because of its high toxicity for aquatic life. In other words, the risk of occurrence of different emergency situations and environmental threats stipulated by use of diphenyl oxide will be kept constant without regard to the strictest control over production.

A durable solution of this problem can be one of the approaches of "green chemistry», namely to refuse to use of potentially toxic solvents. In case of the reaction considered its practical implementation is rather easy since one of the main reagents (triethyl methanetricarboxylate) is perfectly acceptable as an alternative to diphenyl oxide by its physical properties. In fact, addition of $N$-substituted anilines 3-4 into triple excess of triethyl methanetricarboxylate heated to $215-220^{\circ} \mathrm{C}$ gives ethyl esters of the corresponding quinolinecarboxylic acids 1-2 with high yields. It is true that therefrom the additional task appears - regeneration of triethyl methanetricarboxylate taken in excess. However, we have found that upon completion of condensation the excess of this expensive reagent is rather easily returned to production with losses not exceeding 5\% (see Experimental Part).

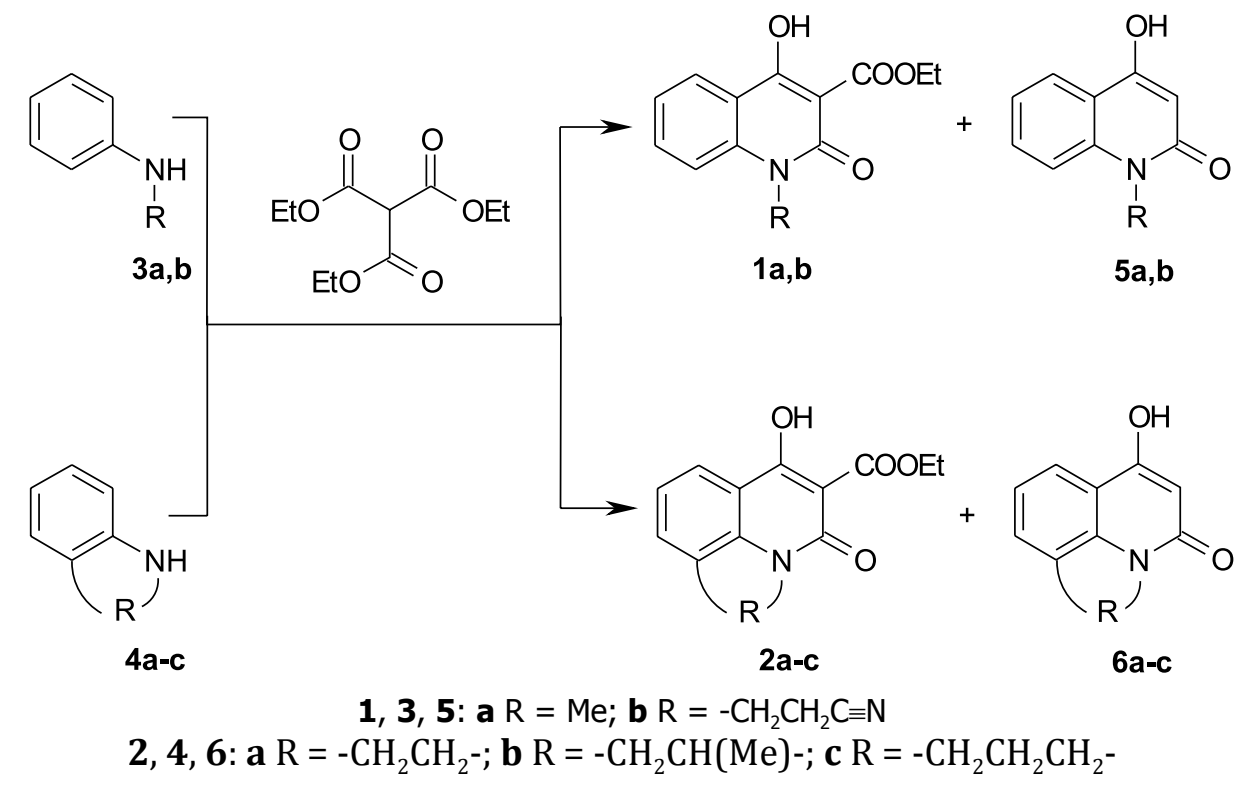

Scheme. The synthesis of ethyl 4-hydroxy-2-oxo-1,2-dihydroquinoline-3-carboxylates $\mathbf{1}$ and $\mathbf{2}$. 
It should be noted that removal of diphenyl oxide from the synthetic scheme is imposed not only with production and ecological safety. The study of quality of the esters $\mathbf{1}$ and $\mathbf{2}$ by HPLC has shown that all of them contain from 2.4 to $5.6 \%$ of specific admixtures of 4-hydroxy-1,2-dihydroquinolin-2-ones $\mathbf{5}$ or $\mathbf{6}$. In laboratory conditions these amounts can be neglected, but for industrial manufacture they can turn into great losses. It is worth remembering one more principle of «green chemistry» - the tendency to introduction of technologies allowing to reduce the yields of undesirable by-products.

The source of admixtures of 3H-quinolines 5-6 appearing in crude esters 1-2 can be only the esters themselves. Our tentative assumption that their partial hydrolysis and subsequent easily proceeding decarboxylation [7] occur at the stage of separation (when treating with a hot aqueous solution of sodium carbonate [8]) or in the process of drying has not been confirmed. In the experiments carried out under conditions that exclude contacts with water the similar results have been obtained. It is obvious that ester grouping is partially destroyed not in the process of separation of the final products, but during the course of the basic reaction. A strong argument in favour of such conclusion is the fact that ethyl esters of 4-hydroxy-2-oxo-1,2-dihydroquinoline-3-carboxylic acids begin to reveal anomalously high sensitivity to water and rapidly decompose at $95^{\circ} \mathrm{C} \mathrm{[12].} \mathrm{It} \mathrm{is} \mathrm{clear} \mathrm{that}$ at $215-220^{\circ} \mathrm{C}$ all water, which present in the reaction mixture, will be inevitably involved in hydrolysis of the resulting cyclic ester $\mathbf{1}$ or $\mathbf{2}$. Therefore, the less water is in initial reagents, the lower is the yield of by-products of 4-hydroxy-1,2-dihydroquinolin-2ones 5 and $\mathbf{6}$. This fact has just become another incentive for refusal of diphenyl oxide use as an additional potentially possible source of water.

To remove water from the main components of the reaction - $N$-substituted anilines and triethyl methanetricarboxylate - can be done by various ways. We believe that it is expedient to use commercially available molecular sieves as drying agents. They have a good desiccant ability, readily regenerate, and, of no less importance, they are environmentally harmless. Finally it should be noted that with introduction of reagents dried in such way into the synthesis the undesired process of $3 \mathrm{H}$-quinolines formation can be completely suppressed. In our experiments their content in crude esters 1-2 did not exceed $0.1 \%$.

Thus, based on detailed study of peculiarities of the reaction of $N$-substituted anilines with triethyl methanetricarboxylate the method, which is simple in performance and at the same time highly effective and suitable for large scale production, for obtaining ethyl esters of 4-hydroxy-2-oxo-1,2-dihydroquinoline-3-carboxylic acids and their tricyclic analogues has been suggested.

\section{Experimental Part}

Identification of the esters $\mathbf{1}$ and $\mathbf{2}$ synthesized is confirmed by NMR ${ }^{1} \mathrm{H}$ spectra recorded on a Varian Mercury-400 spectrometer ( $400 \mathrm{MHz})$ in the solution of DMSO- $\mathrm{d}_{6}$, the internal standard TMS by comparing with the similar spectra of the known samples $[8,12-15]$. Their quantitative analysis is carried out by HPLC using a Waters Alliance 2695 liquid chromatograph with a Waters PDA 2998 diode matrix spectrophotometric detector. The chromatographic conditions are: the analytical column - Agilent Zorbax SB-CN with the size of $4.6 \times 250 \mathrm{~mm}$; the particle size of the sorbent $-5 \mu \mathrm{m}$; the flow rate of the mobile phase $-1 \mathrm{ml} / \mathrm{min}$; the column temperature $-30^{\circ} \mathrm{C}$; the injection volume $-20 \mu \mathrm{cl}$; detection at wavelength of $235 \mathrm{~nm}$. The composition of the mobile phase is the mixture of $0.05 \mathrm{M}$ phosphate buffer solution with pH 3.0 and acetonitrile (55:45). In chromatographic studies as tracking substances the known samples of esters $\mathbf{1}$ and $\mathbf{2}$, as well as $3 \mathrm{H}$-quinolines $\mathbf{5}$ and $\mathbf{6}$ are used.

Ethyl 4-hydroxy-2-oxo-1,2-dihydroquinoline3-carboxylates 1-2 (General Method). In $69.67 \mathrm{~g}$ $(0.3 \mathrm{Mol})$ of triethyl methanetricarboxylate heated to $215-220^{\circ} \mathrm{C}$ add dropwise while stirring $0.1 \mathrm{~mol}$ of the corresponding $N$-substituted aniline $\mathbf{3}$ or $\mathbf{4}$ taking into account the temperature of the reaction mixture, which should be maintained in the range of $215 \pm 5^{\circ} \mathrm{C}$. In case of solid amines (for example, 3 -anilinepropanenitrile $\mathbf{3 b}$ ) to $0.2 \mathrm{Mol}$ of triethyl methanetricarboxylate add $0.1 \mathrm{Mol}$ of aniline solution in $0.1 \mathrm{Mol}$ of triethyl methanetricarboxylate. Remove ethanol liberating in the course of the reaction via a suitable reflux condenser without entrainment of initial reagents. After addition of all aniline, mix the reaction mass for $1 \mathrm{~h}$ at $220^{\circ} \mathrm{C}$ to complete the reaction. Then cool it to $\sim 150^{\circ} \mathrm{C}$, change the reflux condenser to the descending condenser and distill the excess of triethyl methanetricarboxylate under reduced pressure (2-5 $\mathrm{mm} \mathrm{Hg}$ ). On the average $44.3 \mathrm{~g}$ of triethyl methanetricarboxylate, which is available for resynthesis without additional purification, is obtained. While stirring add $200 \mathrm{ml}$ of hexane to the residue cooled to $\sim 70^{\circ} \mathrm{C}$. Gradually while decreasing the temperature the viscous reaction mass is crystallized. Sometimes, for example, in case of ethyl 6-hydroxy-2-methyl-4-oxo-2,4-dihydro- $1 H$-pyrrolo $[3,2,1-i j]$ quinoline-5-carboxylate $(\mathbf{2 b})$ to accelerate crystallization it is useful to add inoculation. Filter the light-yellow precipitate formed, wash with hexane and dry. The yields are $86-97 \%$ with the content of the active substance not less than $94 \%$. The technical esters 1 or $\mathbf{2}$ obtained in such way are suitable for the majority of further chemical transformations without additional purification. 


\section{References}

1. Schulte P.A., McKernan L.T., Heidel D.S. et al. // Environ. Health. - 2013. - Vol. 12-31 / doi: 10.1186/1476069X-12-31.

2. Anastas P.T., Warner J.C. Green Chemistry: Theory and Practice. - New York: Oxford University Press, 1998. P. 30-34.

3. Collin X., Robert J.M., Duflos M. et al. //J. Pharm. Pharmacol. - 2001. - Vol. 53, №3. - P. 417-423.

4. Jönsson S., Andersson G., Fex T. et al. // J. Med. Chem. - 2004. - Vol. 47, №8. - P. 2075-2088.

5. Ukrainets I.V., Mospanova E.V., Bereznyakova N.L., Naboka O.I. // Chem. Heterocycl. Comp. - 2007. - Vol. 43, №12. - P. 1532-1539.

6. Marquess D., Fatheree P.R., Turner D.S. et al. // WO Patent 2005/100350. - 2005.

7. Ukrainets I.V., Davidenko A.A., Mospanova E.V. et al. // Chem. Heterocycl. Comp. - 2010. - Vol. 46, №5. P. 559-568.

8. Ukrainets I.V., Golik N.Yu., Andreeva K.V., Gorokhova O.V. // Chem. Heterocycl. Comp. - 2010. - Vol. 46, №12. - P. 1459-1466.

9. Hefner R.E., Leong B.K., Kociba R.J., Gehring P.J. // Toxicol. Appl. Pharmacol. - 1975. - Vol. 33, Iss. 1. P. 78-86.

10. Hardy M.L. // Chemosphere. - 2002. - Vol. 46, №5. - P. 717-728.

11. Kheifits L.A., Dashunin V.M. Fragrances and Other Products for Perfumes. - Moscow: Khimia, 1994. - P. 154-155.

12. Ukrainets I.V., Golik N.Yu., Shemchuk A.L. et al.//Chem. Heterocycl. Comp. - 2011. - Vol. 47, №7. - P. 826-832.

13. Ukrainets I.V., Gorokhova O.V., Taran S.G. et al. // Chem. Heterocycl. Comp. - 1994. - Vol. 30, №7. - P. 829-836.

14. Ukrainets I.V., Sidorenko L.V., Gorokhova O.V. et al. // Chem. Heterocycl. Comp. - 2006. - Vol. 42, №5. P. 631-635.

15. Ukrainets I.V., Bereznyakova N.L., Grinevich L.A. et al. // Chem. Heterocycl. Comp. - 2010. - Vol. 46, №6. P. 699-710.

Надійшла до редакції 10.06.2013 р. 